\title{
A novel method to assess drought stress of olive tree
}

\author{
Kamel Gargouri • Hatem Bentaher • Ali Rhouma
}

Accepted: 19 December 2011 / Published online: 12 January 2012

(C) INRA and Springer-Verlag, France 2012

\begin{abstract}
Threats of desertification have been projected for the Mediterranean basin under relatively minor warming and drying scenarios. This situation raises the need for mitigation strategies and adaptation of crop production. Crop vulnerability assessment is therefore needed. In Tunisia, olive culture is a major activity. In some cases, olive is the only crop able to grow in local conditions. However, olive production may be among the more vulnerable systems to climate change since perennial crops adapt slowly. No studies have been dedicated to vulnerability evaluation of olive production. Here, the vulnerability of Tunisian olive trees to drought was assessed under extremely low precipitation levels, of $50 \%$ of normal precipitation, from 1999 to 2002. The impact of drought was quantified using a severity scale with three levels. A map of the impact of drought on olive trees was constructed for all Tunisian olive groves. We found that the number of wilting olive trees in 2002 was 7.8 millions of about 60 millions trees. A correlation was observed between olive tree affection by drought and olive orchard age. Thus, under the same drought conditions, senescent orchards were less resistant to drought than young ones. Locally, data showed that compact soils and soils containing more than $1 \%$ gypsum were not suitable for olive growth under drought.
\end{abstract}

Keywords Olea europaea . Olive growing · Drought . Vulnerability · GIS · Soil quality

K. Gargouri $(\bowtie) \cdot H$. Bentaher $\cdot$ A. Rhouma Olive Institute, University of Sfax, Airport road, Po. Box 1087-3000, Sfax, Tunisia e-mail: kamelgargouri@altern.org

K. Gargouri

e-mail: kamel.gargouri@iresa.agrinet.tn

\section{Introduction}

The agricultural sector is sensitive to climate change since plant adaptation to environmental variations is limited. Over the past century throughout the Mediterranean region, climate changes have led to a decrease in rainfall and an increase in temperature (Ragab and Prudhomme 2002). Mediterranean-type ecosystems are located in midlatitudes often on nutrient-poor soils and in coastal regions (Fischlin et al. 2007). In these regions, high temperatures, high deficits in vapor pressure, and reduced water availability are environmental factors that can greatly affect plant production (Chartzoulakis and Psarras 2005).

The most severe impacts of climate changes are likely to come not from the expected increase in temperature but from the changes in precipitation and evapo-transpiration (Ragab and Prudhomme 2002). Because water is the most limiting resource in arid ecosystems, changes in global and regional precipitation regimes, even of relatively small magnitude and short duration, may be expected to have substantial effects (Brown and Rosenberg 1997). Indeed, it was reported that drought occurs frequently in these regions causing significant decreases in crop yield (Boken 2009). Climate change affects crops, agricultural water resources, and crop production in broad regions of the world (IPCC 2001; 2007; Lobell et al. 2006). Threats from desertification have been projected for the Mediterranean basin due to the expansion of adjacent arid systems under relatively minor warming and drying senarios (Fischlin et al. 2007). Reductions in the frequency of the projected rainfall, that have already been observed in the eastern Mediterranean, will exacerbate drought conditions (Körner et al. 2005).

Consequently, natural vegetation is likely to be negatively affected and substantial shifts may be observed. Species loss and turnover may be high under a range of scenarios. 
Indeed, between $60 \%$ and $80 \%$ of current species are projected not to persist (Bakkenes et al. 2002; Thuiller et al. 2005). Cultivated species will also be affected. However, intensive agriculture systems with irrigation and high intrant application rate may probably adapt more easily to these conditions than extensive ones (Chartzoulakis and Psarras 2005).

Tunisia is a southern Mediterranean country, with more than two thirds of its area under arid and semi-arid climates, and drought is assumed to be a natural and frequent hazard affecting agricultural production. In these areas, olive culture is among the most important activities and in some cases the only crop able to grow in these local environmental conditions. The capacity of olive trees to overcome water shortage is well known (Spennemann and Allen 2000; Loumou and Giourga 2003).

Agricultural output is crucial for the Tunisian economy, accounting for $12-16 \%$ of the GDP, depending on the size of the harvest. This sector provides jobs for $22 \%$ of the country's labor force. Olive together with wheat, is one of the most important exported crops, and Tunisia is considered one of the world's biggest producer and exporter of olive oil. Olive groves cover almost one third of all the cultivated land with more than 60 million trees. Annual agricultural production can vary significantly from year to year due to Tunisia's unpredictable and largely irregular rainfall patterns. Severe droughts, such as occurred in 2000 , have had a dramatic cost effect.

Agricultural production has to adapt to the new climate conditions in order to ensure sustainability. This adaptation capacity is highly linked to the vulnerability of the system, which is generally defined as the degree of susceptibility to damage due to a hazardous phenomenon (Tsakiris 2009). The more vulnerable systems in this case are those that adapt slowly such as perennial crops (Petit et al. 2005; Lobell et al. 2006). The olive tree is a perennial plant cultivated in rainfed conditions under the minimum viable rainfall. Moreover, olive cultivars evolve slowly due to their long generation time, reaching in some cases over 100 years, which limits the role of plant breeding and the selection of more adapted cultivars. For these reasons, olive may be one of the crops most at risk. The vulnerability of the olive tree to drought may be examined by analyzing the reaction of olive tree during a previous drought episode. Such vulnerability has not been assessed in Tunisia. Furthermore, no clearly defined methodology was developed worldwide to determine crop vulnerability to drought.

During the period 1999-2002, the Tunisian olive grove faced severe drought induced by a rainfall deficit of over $50 \%$. Tree reactions differed widely even under the same climatic conditions. Indeed, in the same region submitted to the same water deficit, one could observe healthy trees (normal vegetative growth), trees with no growth and even wilting or totally dry trees (Gargouri et al. 2008). This raises the hypothesis that factors other than rainfall deficit influence the vulnerability of olive tree under drought conditions. Indeed, vulnerability to drought is multidimensional (Ubimtseva and Henebry 2009), involving interactions between the physiological capacity of the tree and external factors such as soil type and management systems. Therefore, assessing and mapping olive vulnerability to drought at national and local levels in relation to such factors can provide a useful tool for policy targeting. Such an approach, combining mapping of regional vulnerability with case studies at the local level, led to the identification of areas where policy intervention is most critical for agriculture (O'Brien et al. 2004). The aims of the present study were to develop a national vulnerability map of olive growing under drought stress at district and subdistrict levels, and to identify in a vulnerable district, factors affecting olive vulnerability.

\section{Material and methods}

\subsection{Area studied}

The area studied is located in Tunisia that latitude is ranged from $32^{\circ} 39^{\prime}$ to $37^{\circ} 21^{\prime} \mathrm{N}$ and longitude from $8^{\circ}$ $10^{\prime}$ to $11^{\circ} 33^{\prime} \mathrm{E}$ (Fig. 1a). The climate is Mediterranean with hot dry summers, wet cold winters, and distinct springs and autumns. The country is dominated by three climate types: subhumid, semi-arid, and arid. The subhumid climate with rainfall of more than $800 \mathrm{~mm} / \mathrm{year}$ is located in the north up to the Dorsal, an extension of the Atlas Mountains. In this area, olive cultivation is marginal. The most important part of olive orchards is located southward the Dorsal under semi-arid and arid climates with rainfall ranging between 150 and $450 \mathrm{~mm} /$ year. In these regions, olive growing is usually rainfed and cultivated as monoculture with application of water harvesting and conservation techniques such as capturing and storing rainfall into the soil and limiting evaporation and competition for water by tillage.

\subsection{Identification of drought period}

In Tunisia, agricultural drought is usually declared when rainfall deficit begins to induce a significant decline in crop yields. This is achieved through the analysis of climatic data by the Tunisian National Meteorological Institute (NMI) and the Ministry of Agriculture and environment (MAE). The drought is also confirmed by case studies performed by the National Committee of Drought Impact on Olive Tree Growth. The last drought episode was declared in Tunisia in the end of the nineties. The beginning and the end of drought were identified according to deciles (Gibbs and 


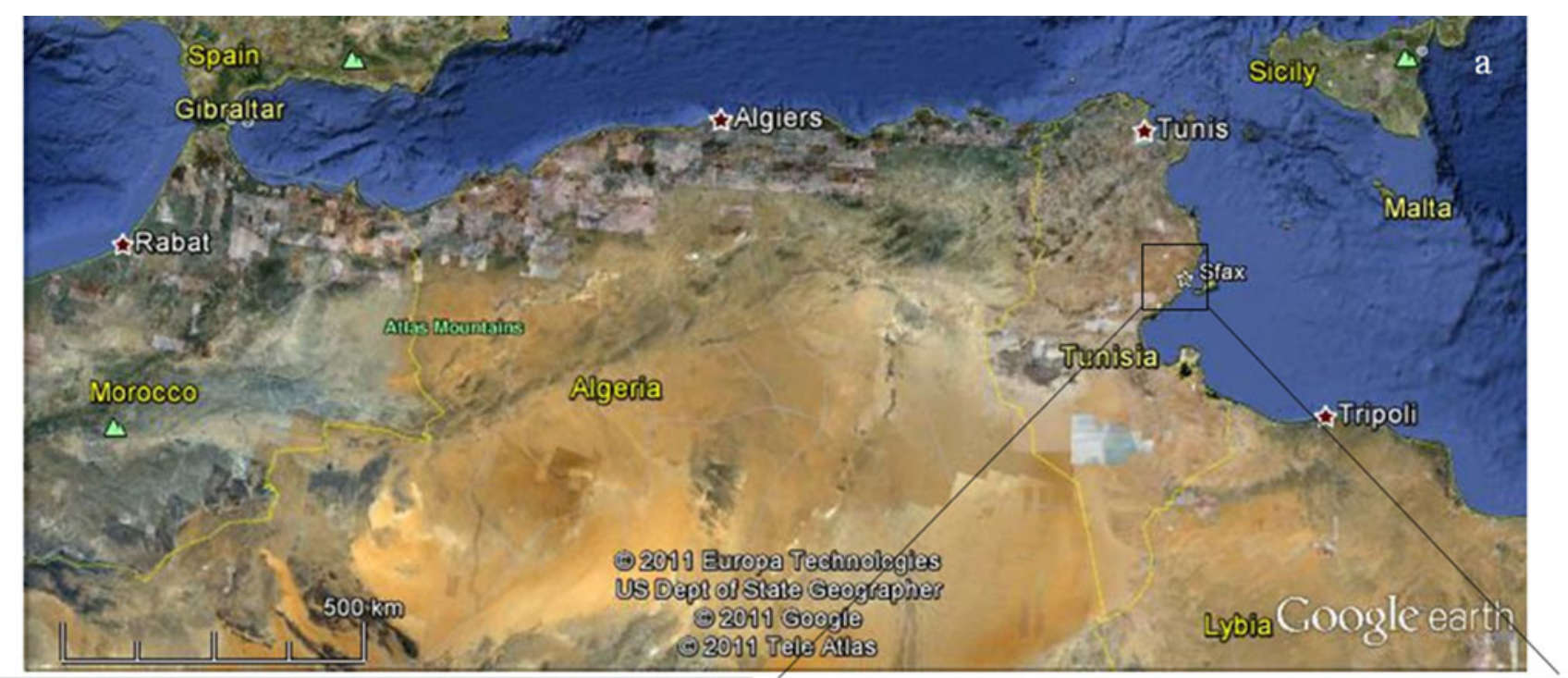

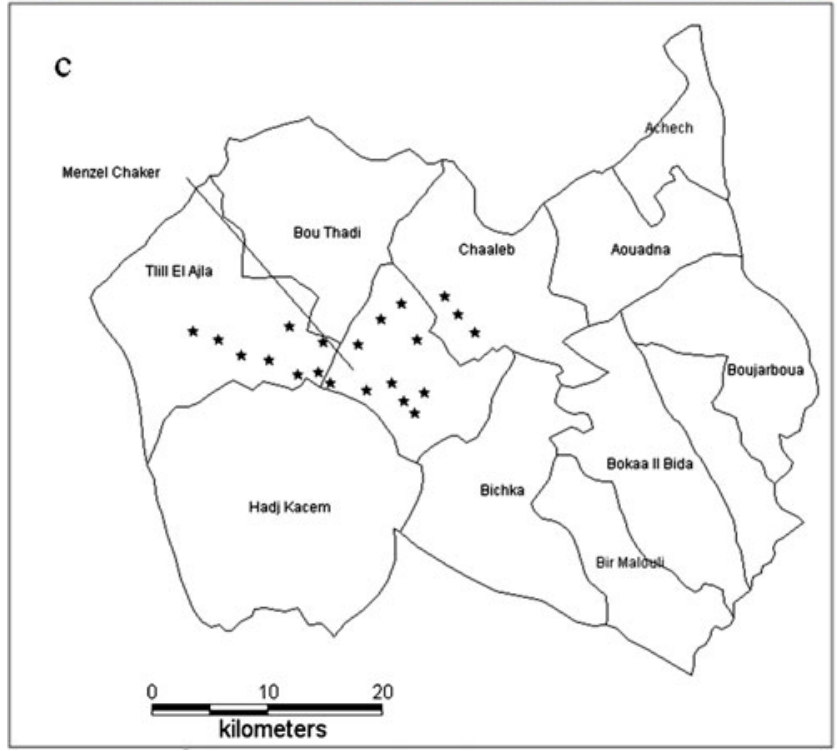

Fig. 1 Maps showing the location of Tunisia in North Africa and the Mediterranean (source Google earth) with the situation of Sfax region in the square (a), the location Sfax and Menzel Chaker district (in the

Maher 1967). The precipitations for the preceding 3 months are ranked against climatologic records. If the sum falls within the lowest decile, the region is considered to be under drought conditions. The drought ends when the previous condition is invalidated by a month addition (Tsakiris and Pangalou 2009).

\subsection{Calculation of rainfall deficit}

The relative rainfall deficit is defined as the percentage below the average long-term rainfall. The rainfall was registered for an agricultural year beginning September 1 and finishing August 31. The long-term climatic data series were obtained from NMI (at least 32 years up to 115 years).

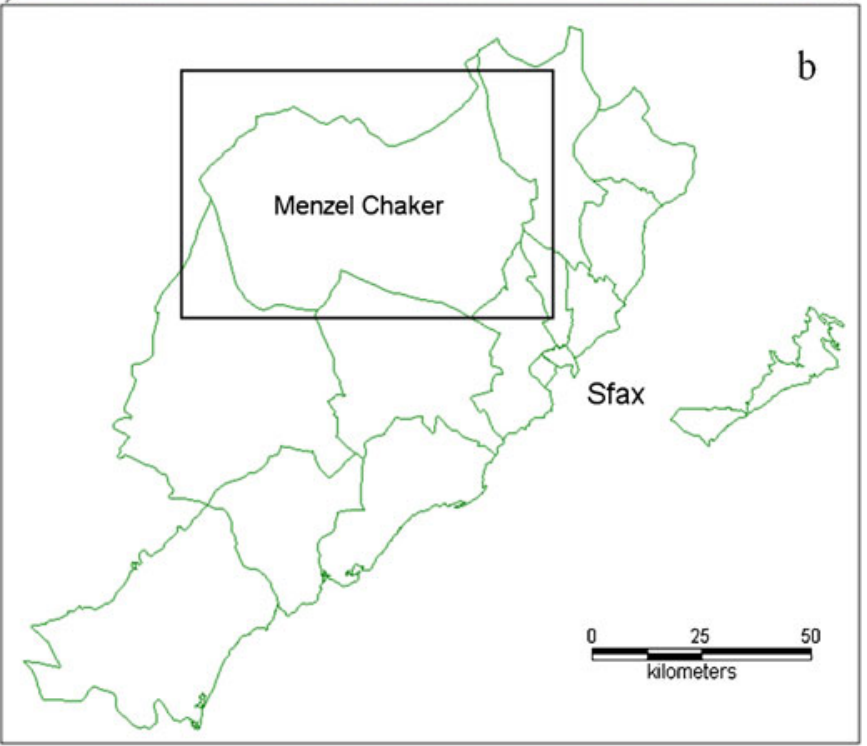

square) where soil study was performed (b) and Menzel Chaker district with the location of soil profiles identified by stars (c)

\subsection{Length and geographic extent of drought period}

An agricultural year (September 1 to August 31) was assumed to be a dry year when a dry autumn was followed by a dry spring. When this condition is not fulfilled, the agricultural year is considered out of drought. Since 1999, a 3- to 4-year drought period was detected in all inland and southern regions, while in the central costal area, this drought was 2 years long.

During the drought period, the mean annual rainfall deficit as compared to the mean long-term rainfall was determined for selected locations of the Center and South of Tunisia in coastal and inland areas (Table 1). The longterm rainfall mean varied from $153 \mathrm{~mm} /$ year in Medenine in the southern coastal area to $318 \mathrm{~mm} /$ year in the central 
Table 1 Long-term rainfall means and rainfall means and deficit during drought in seven selected locations in the area under drought

\begin{tabular}{lllc}
\hline Location & $\begin{array}{l}\text { Long-term rainfall mean } \\
(\mathrm{mm})\end{array}$ & $\begin{array}{l}\text { Rainfall mean during } \\
\text { drought }(\mathrm{mm})\end{array}$ & $\begin{array}{l}\text { Rainfall deficit mean } \\
(\mathrm{mm} / \text { year})\end{array}$ \\
\hline $\begin{array}{c}\text { Monastir } \\
\text { (center-east) }\end{array}$ & $317.8(1980 / 81-2001 / 02)$ & $183.5(2000 / 01-2001 / 02)$ & $134.3(42.3 \%)$ \\
$\begin{array}{l}\text { Sfax (center-east) } \\
\text { Kairouan }\end{array}$ & $200.5(1930 / 31-2001 / 02)$ & $118.4(1999 / 00-2001 / 02)$ & $82.1(40.9 \%)$ \\
$\quad$ (center-west) & $301.4(1915 / 16-2001 / 02)$ & $194.6(1999 / 00-2001 / 02)$ & $106.8(35.4 \%)$ \\
$\begin{array}{c}\text { Sidi Bouzid } \\
\quad \text { (center-west) }\end{array}$ & $309.4(1971 / 72-2001 / 02)$ & $149.1(1999 / 00-2001 / 02)$ & $160.3(51.8 \%)$ \\
$\begin{array}{c}\text { Gabes (south-east) } \\
\text { Mednine } \\
\quad \text { (south-east) }\end{array}$ & $185.7(1885 / 86-2001 / 02)$ & $96.3(1999 / 00-2001 / 02)$ & $89.4(48.1 \%)$ \\
Gafsa (south-west) & $153.4(1903 / 04-2001 / 02)$ & $82.5(1999 / 00-2001 / 02)$ & $70.9(46.2 \%)$ \\
\hline & & $99.8(1999 / 00-2001 / 02)$ & $69.7(41.1 \%)$ \\
\hline
\end{tabular}

coastal area in Monastir. The average rainfall deficit during the drought period ranged between $70 \mathrm{~mm} /$ year in the southern area and $160 \mathrm{~mm} /$ year in the central west area. However, the minimum and maximum relative mean rainfall deficit as compared to the long-term rainfall mean were recorded in two neighboring locations of the central western part, i.e., $35 \%$ in Kairouan and 52\% in Sidi Bouzid.

\subsection{The impact of drought on olive production}

To assess the impact of drought on olive production and thereafter on farmers' income, the production of 2001 was compared to the average production over 10 years before drought in each of the selected areas. Olive production in rainfed orchards was reduced by $42.8 \%$ in the north, while it decreased much more dramatically in the other regions, i.e., $86.0 \%$ in the center, and $84.1 \%$ in the southwest. Thus, the olive production was greatly reduced in all the main producing areas (General Direction of Agricultural Production of MAE, unpublished data). This decrease in production was also observed for the entire country that dropped by $82.1 \%$ : the average production during the previous decade was $837,500 \mathrm{t}$ of olives while it was only $150,000 \mathrm{t}$ in 2001 (FAO 2010).

\subsection{Mapping of Tunisian olive-growing vulnerability}

The vulnerability of the olive-growing sector to drought was assessed by the analysis of the reaction of olive trees to the last drought episode. A digital map of Tunisia was drawn involving polygons corresponding to 234 subdistricts (small administrative localities). This was achieved using the MapInfo Professional 6.0 software (MapInfo Corporation, USA). A database was then created for the impact of drought on local olive groves. This database contains data for all the olive trees, the surface covered by the olive orchards, climatic data, and the status of the rainfed olive trees. The status of the rainfed trees was quantified based on a three-level scale established as follows: 1, normal growth and development; 2, growth arrest without wilting; and 3, wilting until death of the tree. Olive data were obtained from the General Direction of Agricultural Production of the Ministry of Agriculture and Environment and through surveys with local agricultural authorities in every district. The survey was conducted during March and April 2002; this period is an active period for olive tree with normally important vegetative growth. Thus, it was trouble-free to detect whether there was new shoots or not. The presence of new shoots indicated the normal growth status while their absence indicated the stopped growth. The olive tree was classified in the third class when drying shoots and leaves with brown color were detected. The percentage of trees belonging to the third category, as compared to the total number of olive trees, was calculated for every subdistrict. The geographical distribution of this parameter was then introduced on the digital map representing the 234 subdistricts.

2.7 Assessment of the factors influencing olive vulnerability

To investigate the factors influencing the capacity of olive trees to face drought, the study was continued on a small scale in the region of Sfax situated in the center of Tunisia with 6 million olive trees belonging to 16 districts. It covers $7,596 \mathrm{~km}^{2}$ and its latitude ranges from $34^{\circ} 16^{\prime}$ to $35^{\circ} 10^{\prime} \mathrm{N}$ and its longitude from $10^{\circ} 03^{\prime}$ to $10^{\circ} 55^{\prime} \mathrm{E}$. The survey was carried out in two ways:

1 correlation matrix was performed for the average annual rainfall during drought, average annual rainfall deficit during drought, percentage of senescent trees (more than 80 years old) as compared to the total number of trees, and the olive tree status by SPSS 13.0 for windows (SPSS Inc. USA). The age of olive trees was obtained from the General Direction of Agricultural Production of the Ministry of Agriculture and Environment and confirmed through surveys with local agricultural authorities in every district. Linear regressions were then carried out 
for correlated parameters using CurveExpert 1.38 (Microsoft Corporation, USA).

2 Geographical information system (GIS) tools were used to superpose the olive tree status map involving the three levels and maps of average annual rainfall during drought, the average annual rainfall deficit during drought and the percentage of senescent trees.

\subsection{Soil quality}

The effect of soil quality on the behavior of olive trees under drought conditions was studied in a small limited zone, corresponding to the Menzel Chaker district that belongs to the Sfax district and has more than 2 million olive trees (Fig. 1b). Its latitude ranges from $35^{\circ} 00^{\prime}$ to $35^{\circ} 04^{\prime} \mathrm{N}$ and its longitude from $10^{\circ} 03^{\prime}$ to $10^{\circ} 18^{\prime} \mathrm{E}$. Twenty-one soil profiles were realized up to $1.5 \mathrm{~m}$ depth using an excavator (Fig. 1c). These profiles were studied in different orchards belonging to one governmental farm so as to be sure that the chosen parcels received the same farming practices. This farm covers 18,000 ha, among them 7,500 ha of olive groves. The profiles were realized in orchards having olive of the same age with different status. Basing on these conditions, eight orchards were selected. In addition, for every apparent soil variation within one orchard, a new profile was realized. The focus was done on areas having neighboring healthy and suffering trees. Every soil profile was described by a pedologist, who identified soil horizons and their depth. Presence of olive roots was recorded for every horizon. Compound soil samples (three subsamples) were taken from every horizon using a core sampler. These samples were analyzed to assess soil depth, and the amounts of organic matter, gypsum, lime, sand, silt, and clay. Soil samples were air-dried overnight and passed through a 2-mm sieve. The content in organic matter was determined according to the method of Walkley and Black (Pauwels et al. 1992). To determine the amount of calcium carbonate, $\mathrm{HCl}(1 \mathrm{~N})$ was applied on the soil and the part consumed was estimated by titrating the unconsumed part (Pauwels et al. 1992). Gypsum $\left(\mathrm{CaSO}_{4} \cdot 2 \mathrm{H}_{2} \mathrm{O}\right)$ was dissolved in a solution of ammonium carbonate (5\%), the addition of barium chloride to the solution precipitates the sulfates produced as barium sulfates (Pauwels et al. 1992). Soil texture was determined following the hydrometer method. The amount of sand, silt, and clay in the soil sample is determined, after dispersion with sodium metaphosphate, by a hydrometer, which measures the particles in suspension. The amount of each type of particle is determined using Stokes' Law, which determines the amount of each particle type present by the rate at which each particle type falls out of suspension, based on its size. Then, soil structural type is determined according to the United States Department of Agriculture texture triangle (Brown 2003).

\section{Results and discussion}

\subsection{Mapping of Tunisian olive-growing vulnerability}

The determination of the number of olive trees at the subdistrict level in Tunisia showed that olive trees are present everywhere in Tunisia (Fig. 2a), even in the desertic part of the country located in the south and inland. However, the desertic subdistricts contain very few olive trees. In these areas, the olive tree grows only in oases due to their special microclimate. It was reported that air dryness and the rain's dearth determine the southern limit of olive tree expansion (Loumou and Giourga 2003). Olive trees grow in oases because of adequate water regime that allows them to tolerate high summer temperatures. Under these conditions, thanks to some specific morphological and physiological adaptations, olive trees were able to support temperatures above $40^{\circ} \mathrm{C}$. The presence of a cuticle and of overlapping peltate trychomes covering the leaves, and the relative lightness of the canopy enable them to tolerate not only high temperatures, but also hot and dry winds of the Sahara (Fresco 1996).

Despite the adaptation of olive trees to water scarcity and high temperatures, the major part of the Tunisian olive orchards in the main producing regions was affected by the drought of 1999-2002 (Fig. 2b). However, the olive orchards showing the highest percentages of wilting trees are located in the eastern part of the country in two locations. The first one is in the center covering the regions called Sahel and Sfax that produce about $50 \%$ of the national olive production. The second is located in the third most important producing region positioned in the south. The total number of wilting olive trees was more than 7.8 millions corresponding to $13 \%$ of the whole number of olive trees and a surface of 200,000 ha. Moreover, this drought also had an important impact on the local human population especially the rural population since the olive trees are located in regions where olive culture is the only economically viable agricultural crop (Gargouri et al. 2008). In the north, where the water deficit was less important, no suffering trees were detected due to the resistance capacity of the olive tree. In these regions, healthy olive trees of the same cultivar were detected in the neighborhood of suffering trees.

\subsection{Assessment of the factors influencing olive tree vulnerability}

The assessment of the factors responsible for olive tree vulnerability was performed at a small level in the district of Sfax. The bivariate correlation matrix showed that the percentage of wilting trees in 2002 was significantly ( $p<$ $0.01)$ correlated with the percentage of senescent olive trees 

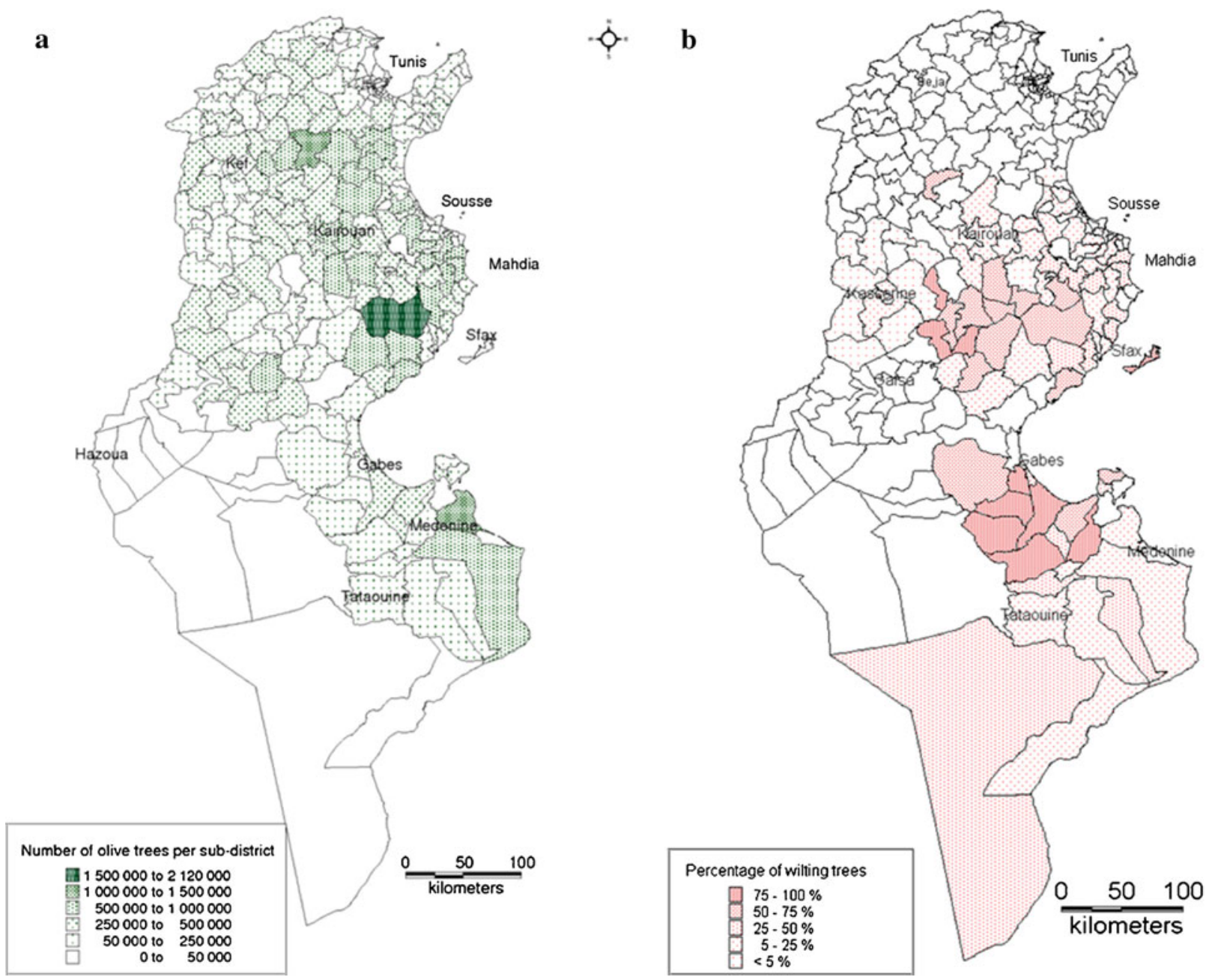

-i.

Fig. 2 Maps showing olive tree distribution in Tunisia (a) and proportion of wilting olive trees due to drought during 1999-2002 (b)

by subdistrict (Table 2). The average rainfall amount and rainfall deficit for the period 1999-2002 were not significantly correlated with olive tree status indicators. The expected effect of rainfall deficit was not clearly established. A high rainfall deficit did not cause a high percentage of wilting olive trees (Fig. 3a). Furthermore, there was no good superposition between the importance of rainfall deficit and the olive tree status (Fig. 3b). Indeed, a district with high deficit did not automatically present a high proportion of suffering trees. For instance, the Sfax-el-Madina district (in

Table 2 Correlation matrix established for average rainfall during drought, average rainfall deficit (1999-2002), olive tree age and status in 2002

\begin{tabular}{llllll}
\hline & $\begin{array}{l}\text { \% of senescent } \\
\text { trees }\end{array}$ & $\begin{array}{l}\text { Rainfall mean during } \\
\text { drought }\end{array}$ & $\begin{array}{l}\text { Rainfall } \\
\text { deficit }\end{array}$ & $\begin{array}{l}\text { Normal } \\
\text { growth }\end{array}$ & $\begin{array}{l}\text { Growth } \\
\text { stopped }\end{array}$ \\
\hline $\begin{array}{l}\text { Senescent \% } \\
\text { Rainfall mean during } \\
\text { drought }\end{array}$ & -0.009 & - & & \\
Rainfall deficit & -0.240 & 0.520 & - & & - \\
Normal growth & -0.496 & -0.363 & -0.309 & - & -0.367 \\
Growth stopped & 0.152 & 0.195 & 0.273 & -0.207 & - \\
Wilting reaching death & $0.892^{\mathrm{a}}$ & 0.059 & -0.252 & $-0.586^{\mathrm{b}}$ & 0.207 \\
\hline
\end{tabular}

Number of observations $=12$

${ }^{\text {a }}$ Correlation is significant at the 0.01 level (two-tailed)

${ }^{\mathrm{b}}$ Correlation is significant at the 0.05 level (two-tailed) 


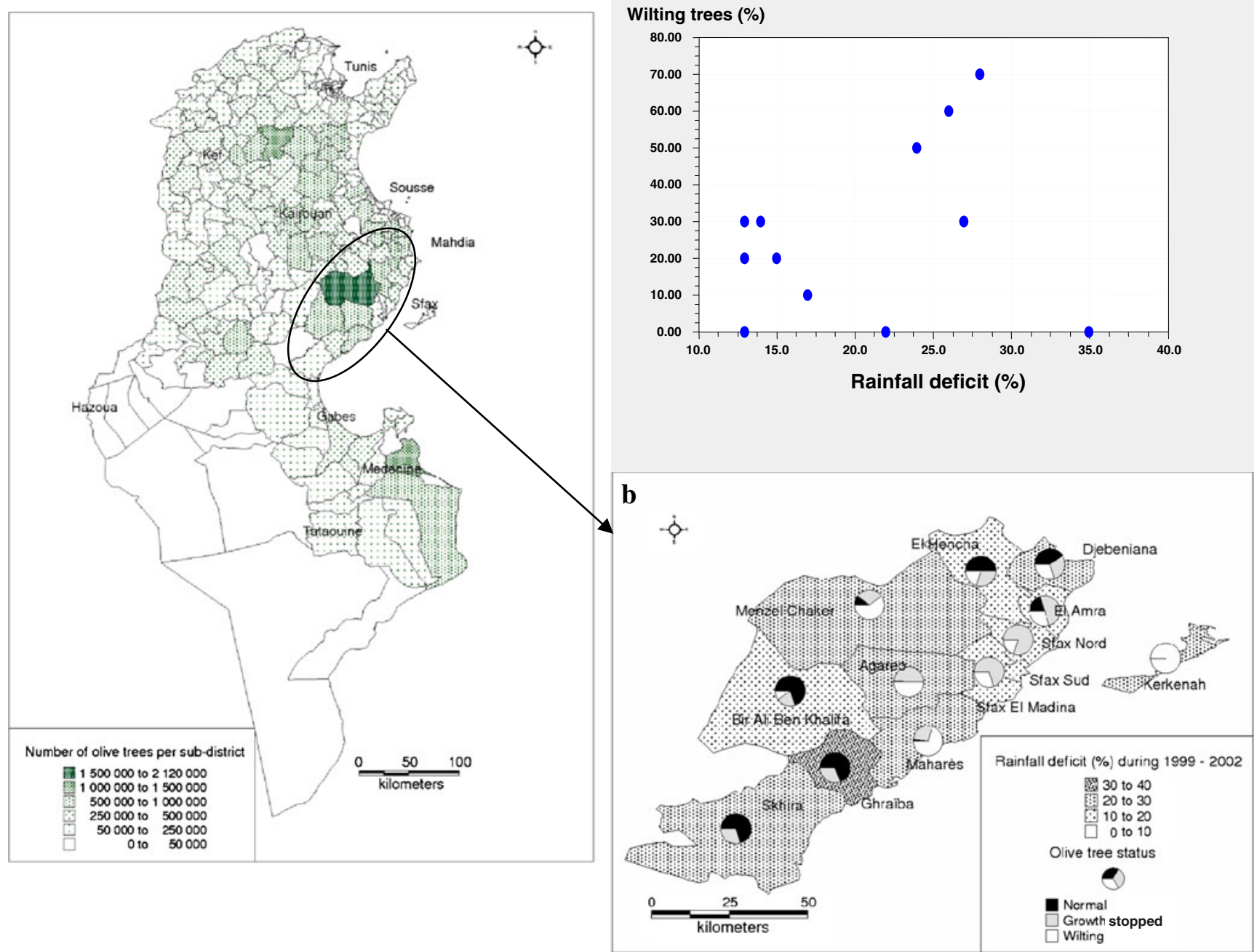

Fig. 3 Relationship between olive tree status in 2002 and cumulated rainfall deficit during 1999-2002, a linear regression, b superposition of the maps of the two studied parameters

the center East of the Sfax region) less than $15 \%$ deficit but no healthy trees while the Ghraiba district (in the south of the Sfax region) had more than $25 \%$ of deficit and about $60 \%$ of trees with normal growth.

The linear regression drawn between percentage of wilting trees and percentage of senescent trees showed a determination coefficient of 0.8 and a standard error of 11.14 indicating the interdependency of these two parameters (Fig. 4a). The maps of the behavior and age of olive trees were well connected (Fig. 4b). The districts with the highest percentage of old trees (more than 80 years) displayed the highest proportion of class three trees (wilting). For example, the Agareb district containing more than $25 \%$ old trees had about $50 \%$ wilting olive trees, while the Ghraiba district where the deficit was more pronounced, showed no wilting olive tree. In this subdistrict, the percentage of old trees was less than $5 \%$. Old olive trees seem to be less capable of resisting water shortage than young trees. Fabbri et al. (2004) reported that during senescence of the olive tree, all processes typical of aging, such as low vegetative activity, reduction of expansion of the root system, susceptibility to diseases, etc. are observed. Consequently, at this stage, the capacity of the tree to develop resistance mechanisms against abiotic stress is reduced (Sofo et al. 2007). Indeed, a reduced rooting system limits the volume of soil, which is the water container, exploited by the tree, and low vegetative activity reduces intrinsic adaptation ability. Under drought conditions, aged olive trees face enhanced water scarcity due to limited access to deep water reserves. In addition, anatomical and physiological adaptation mechanisms such as maintaining high photosynthetic rates with low values of stomatal conductance, (Chratzoulakis et al. 1999) seem to be greatly affected by the reduced vegetative activity. 

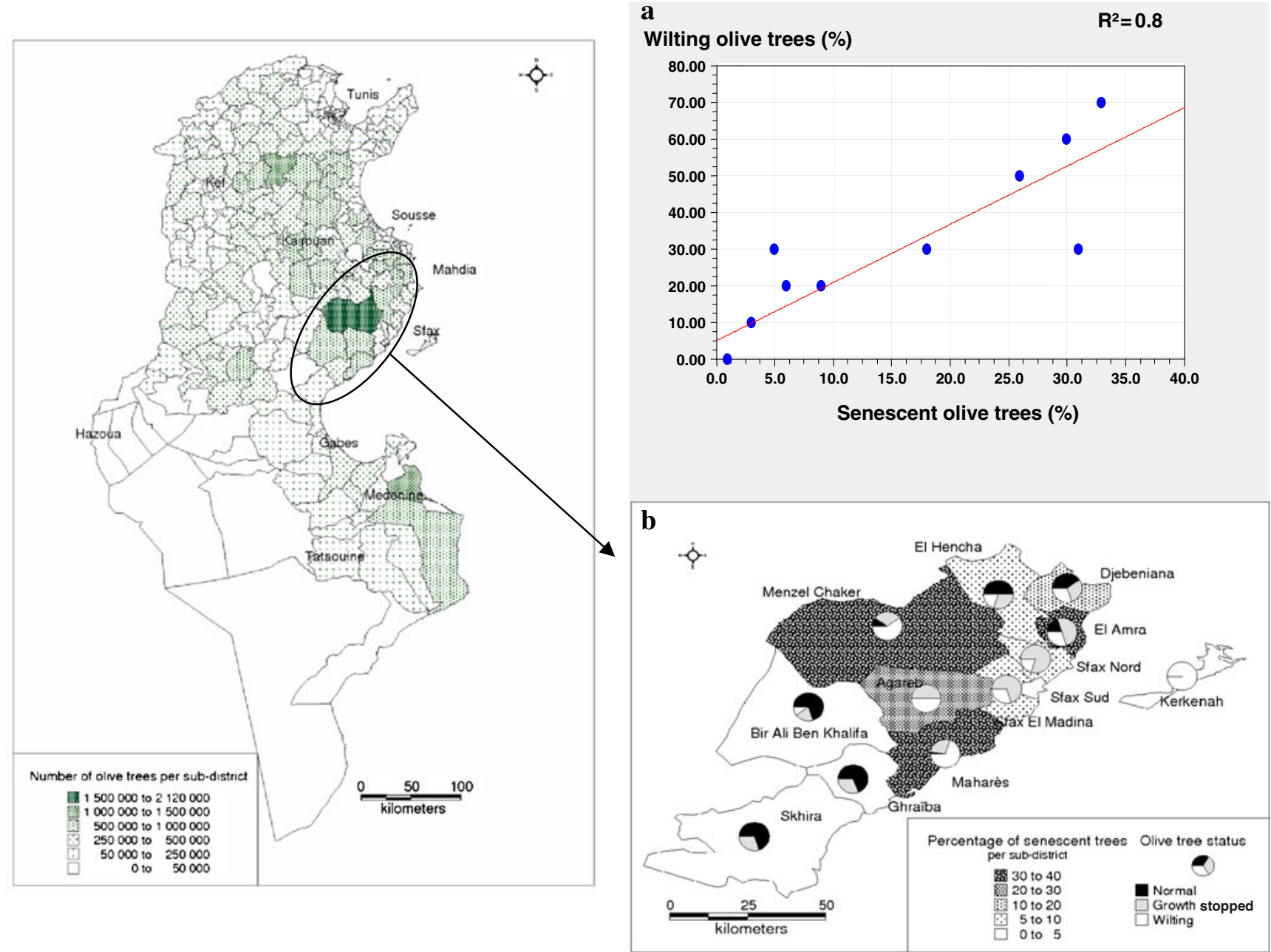

Fig. 4 Map showing the relationship between olive tree status in 2002 and the proportion of old trees, a linear regression, b superposition of the maps of the two studied parameters

\subsection{Soil quality effects}

The effect of soil quality on the response of olive trees to drought was assessed at the subdistrict level in the Menzel Chaker region (Table 3). All the profiles studied had calcareous soil with a low content of organic matter. Nevertheless, olive trees cultivated in deep soil with light texture showed good resistance to water deficit. Indeed, in sandy and loamy sandy soils, the olive trees resisted water deficit except for Mabrouka II location where olive growth was stopped (Table 3). It appears that the powerful root system of the olive tree was able to colonize a large volume of soil and can consequently benefit from a large water reserve (Fresco 1996).

Soils with constraints to root development and mobilization of water (e.g. the Chaaleb I, II and III profiles with increasing deep clay content and compaction, and Aitha II, IV, and V with a calcareous crust) induced more or less accentuated drying symptoms on olive trees (Table 3). Soils with more than 1\% gypsum, especially in the top soil but even in deep layers, were not suitable for the growth of olive trees under drought conditions, and wilting olive trees were observed only in this type of soil (Table 3). Physical constraints such as calcareous crust and gypsum (even at low concentrations) may limit water availability and deep root development. We observed that the layers containing gypsum were not colonized by olive roots. This fact was also described by Francis et al. (2007) for wild species of Namaqualand in South Africa. Soils containing gypsum were considered as marginal for agricultural activities due to their low water and nutrient retention capacity (Herrero and Porta 2000), notwithstanding that the amount of gypsum in their study was much higher than those observed in our case.

The action of gypsum seems to be strongly influenced by other soil and climatic conditions. The fine soil texture, compactness, and water scarcity increased 
Table 3 Soil types and olive tree status

\begin{tabular}{|c|c|c|c|c|c|c|c|}
\hline Locations & $\begin{array}{l}\text { Depth } \\
(\mathrm{cm})\end{array}$ & $\begin{array}{l}\mathrm{CaCO}_{3} \\
(\%)\end{array}$ & $\begin{array}{l}\text { Gypsum } \\
(\%)\end{array}$ & $\begin{array}{l}\mathrm{SOM}^{\mathrm{a}} \\
(\%)\end{array}$ & Soil type & Roots $^{b}$ & Olive status \\
\hline Sulamite I & $\begin{array}{c}0-80 \\
80-100\end{array}$ & $\begin{array}{l}6.5 \\
17.5\end{array}$ & $\begin{array}{l}0.62 \\
0.20\end{array}$ & $\begin{array}{l}0.41 \\
0.55\end{array}$ & $\begin{array}{l}\text { Sand } \\
\text { Loamy sand }\end{array}$ & $\begin{array}{l}\text { Abundant } \\
\text { Abundant }\end{array}$ & Normal \\
\hline B. Romdhan & $\begin{array}{c}0-40 \\
40-60 \\
60-100\end{array}$ & $\begin{array}{l}14.0 \\
11.5 \\
27.0\end{array}$ & $\begin{array}{l}0.16 \\
0.82 \\
1.03\end{array}$ & $\begin{array}{l}0.69 \\
0.76 \\
0.55\end{array}$ & $\begin{array}{l}\text { Loamy sand } \\
\text { Sand } \\
\text { Sandy clay loam }\end{array}$ & $\begin{array}{l}\text { Present } \\
\text { Abundant } \\
\text { Absent }\end{array}$ & $\begin{array}{l}\text { Wilting reaching } \\
\text { death }\end{array}$ \\
\hline Ennajeh I & $\begin{array}{c}0-50 \\
50-100\end{array}$ & $\begin{array}{l}16.8 \\
20.8\end{array}$ & $\begin{array}{l}0.28 \\
0.41\end{array}$ & $\begin{array}{l}0.41 \\
0.28\end{array}$ & $\begin{array}{l}\text { Sandy loam } \\
\text { Sandy clay loam }\end{array}$ & $\begin{array}{l}\text { Present } \\
\text { Few }\end{array}$ & Growth stopped \\
\hline Ennajeh II & $\begin{array}{c}0-40 \\
40-120\end{array}$ & $\begin{array}{l}13.8 \\
30.3\end{array}$ & $\begin{array}{l}0 \\
0.21\end{array}$ & $\begin{array}{l}0.28 \\
0.69\end{array}$ & $\begin{array}{l}\text { Sandy loam } \\
\text { Sandy clay loam }\end{array}$ & $\begin{array}{l}\text { Present } \\
\text { Few }\end{array}$ & Growth stopped \\
\hline Ennajeh III & $\begin{array}{c}0-20 \\
20-50 \\
50-90 \\
90-110\end{array}$ & $\begin{array}{l}21.5 \\
18.3 \\
28.3 \\
16.3\end{array}$ & $\begin{array}{l}0.22 \\
0.16 \\
0.64 \\
9.10\end{array}$ & $\begin{array}{l}0.69 \\
0.76 \\
0.62 \\
0.48\end{array}$ & $\begin{array}{l}\text { Sandy loam } \\
\text { Sandy clay loam }\end{array}$ & $\begin{array}{l}\text { Present } \\
\text { Few } \\
\text { Absent } \\
\text { Absent }\end{array}$ & $\begin{array}{l}\text { Wilting reaching } \\
\text { death }\end{array}$ \\
\hline Ennajeh IV & $\begin{array}{c}0-40 \\
40-100\end{array}$ & $\begin{array}{l}12.3 \\
19.5\end{array}$ & $\begin{array}{l}0.67 \\
0.49\end{array}$ & $\begin{array}{l}0.62 \\
0.62\end{array}$ & $\begin{array}{l}\text { Sandy loam } \\
\text { Sandy clay loam }\end{array}$ & $\begin{array}{l}\text { Present } \\
\text { Few }\end{array}$ & Normal \\
\hline Ennajeh V & $\begin{array}{r}0-20 \\
20-45 \\
45-80\end{array}$ & $\begin{array}{l}30.3 \\
24.3 \\
19.5\end{array}$ & $\begin{array}{l}7.53 \\
3.43 \\
9.61\end{array}$ & $\begin{array}{l}0.34 \\
0.48 \\
0.34\end{array}$ & $\begin{array}{l}\text { Sandy loam } \\
\text { Sandy clay loam }\end{array}$ & $\begin{array}{l}\text { Present } \\
\text { Few } \\
\text { Absent }\end{array}$ & $\begin{array}{l}\text { Wilting reaching } \\
\text { death }\end{array}$ \\
\hline Mabrouka I & $\begin{array}{c}0-15 \\
15-45 \\
45-100\end{array}$ & $\begin{array}{l}9.0 \\
14.3 \\
30.3\end{array}$ & $\begin{array}{l}0.70 \\
0.64 \\
0.47\end{array}$ & $\begin{array}{l}0.34 \\
0.48 \\
0.48\end{array}$ & Loamy Sand & $\begin{array}{l}\text { Present } \\
\text { Few } \\
\text { Few }\end{array}$ & Normal \\
\hline Mabrouka II & $\begin{array}{c}0-40 \\
40-70 \\
70-100\end{array}$ & $\begin{array}{l}27.8 \\
5.0 \\
5.5\end{array}$ & $\begin{array}{l}0.26 \\
0.20 \\
1.26\end{array}$ & $\begin{array}{l}0.48 \\
0.41 \\
0.21\end{array}$ & Loamy Sand & $\begin{array}{l}\text { Present } \\
\text { Few } \\
\text { Few }\end{array}$ & Growth stopped \\
\hline Mabrouka III & $\begin{array}{c}0-30 \\
30-60 \\
60-100\end{array}$ & $\begin{array}{l}14.3 \\
16.5 \\
45.5\end{array}$ & $\begin{array}{l}0.60 \\
0.09 \\
0.55\end{array}$ & $\begin{array}{l}0.48 \\
0.62 \\
0.55\end{array}$ & Loamy Sand & $\begin{array}{l}\text { Present } \\
\text { Few } \\
\text { Few }\end{array}$ & Normal \\
\hline Erriadh I & $\begin{array}{c}0-40 \\
40-70 \\
70-100\end{array}$ & $\begin{array}{l}18.3 \\
20.8 \\
20.0\end{array}$ & $\begin{array}{l}0.72 \\
0.27 \\
0\end{array}$ & $\begin{array}{l}0.83 \\
0.76 \\
0.55\end{array}$ & Sandy clay loam & $\begin{array}{l}\text { Present } \\
\text { Few } \\
\text { Few }\end{array}$ & Growth stopped \\
\hline Erriadh II & $\begin{array}{c}0-25 \\
25-60 \\
60-120\end{array}$ & $\begin{array}{l}8.0 \\
19.3 \\
45.5\end{array}$ & $\begin{array}{l}0.43 \\
0.07 \\
0.49\end{array}$ & $\begin{array}{l}0.41 \\
0.62 \\
0.48\end{array}$ & Sandy clay loam & $\begin{array}{l}\text { Present } \\
\text { Present } \\
\text { Few }\end{array}$ & Normal \\
\hline Chaaleb I & $\begin{array}{r}0-30 \\
30-50\end{array}$ & $\begin{array}{l}12.8 \\
14.8\end{array}$ & $\begin{array}{l}0.74 \\
0.96\end{array}$ & $\begin{array}{l}0.83 \\
1.10\end{array}$ & $\begin{array}{l}\text { Sandy loam } \\
\text { Sandy clay loam }\end{array}$ & $\begin{array}{l}\text { Present } \\
\text { Few }\end{array}$ & Growth stopped \\
\hline Chaaleb II & $\begin{array}{c}0-25 \\
25-100\end{array}$ & $\begin{array}{l}17.0 \\
27.8\end{array}$ & $\begin{array}{l}0.54 \\
0.37\end{array}$ & $\begin{array}{l}0.48 \\
0.55\end{array}$ & $\begin{array}{l}\text { Sandy loam } \\
\text { Sandy clay loam }\end{array}$ & $\begin{array}{l}\text { Present } \\
\text { Few }\end{array}$ & Growth stopped \\
\hline Chaaleb III & $\begin{array}{c}0-20 \\
20-60 \\
60-100\end{array}$ & $\begin{array}{l}8.0 \\
19.3 \\
45.5\end{array}$ & $\begin{array}{l}0.36 \\
0.76 \\
0.05\end{array}$ & $\begin{array}{l}0.48 \\
0.55 \\
0.48\end{array}$ & $\begin{array}{l}\text { Sandy loam } \\
\text { Sandy clay loam }\end{array}$ & $\begin{array}{l}\text { Present } \\
\text { Few } \\
\text { Few }\end{array}$ & Growth stopped \\
\hline GP13 & $\begin{array}{c}0-20 \\
20-50 \\
50-80 \\
80-100\end{array}$ & $\begin{array}{l}18.0 \\
28.3 \\
26.0 \\
20.3\end{array}$ & $\begin{array}{l}0.33 \\
0.39 \\
0.57 \\
2.00\end{array}$ & $\begin{array}{l}0.55 \\
0.41 \\
0.41 \\
0.34\end{array}$ & $\begin{array}{l}\text { Loamy sand } \\
\text { Sand } \\
\text { Sandy clay loam }\end{array}$ & $\begin{array}{l}\text { Present } \\
\text { Abundant } \\
\text { Few } \\
\text { Few }\end{array}$ & $\begin{array}{l}\text { Wilting reaching } \\
\text { death }\end{array}$ \\
\hline Aitha I & $\begin{array}{c}0-10 \\
10-50 \\
50-110\end{array}$ & $\begin{array}{l}8.3 \\
9.3 \\
12.5\end{array}$ & $\begin{array}{l}2.8 \\
1.9 \\
3.6\end{array}$ & & $\begin{array}{l}\text { Sand } \\
\text { Loamy Sand }\end{array}$ & $\begin{array}{l}\text { Present } \\
\text { Abundant } \\
\text { Few }\end{array}$ & Growth stopped \\
\hline Aitha II & $\begin{array}{r}0-10 \\
10-45 \\
45-75\end{array}$ & $\begin{array}{l}5.8 \\
14.3 \\
27.3\end{array}$ & $\begin{array}{l}2.8 \\
3.7 \\
2.9\end{array}$ & & $\begin{array}{l}\text { Sand } \\
\text { Loamy Sand with concrete } \\
\text { Calcareous crust }\end{array}$ & $\begin{array}{l}\text { Present } \\
\text { Abundant } \\
\text { Absent }\end{array}$ & Growth stopped \\
\hline Aitha III & $\begin{array}{r}0-10 \\
10-70\end{array}$ & $\begin{array}{l}12.5 \\
17.3\end{array}$ & $\begin{array}{l}0.7 \\
1.9\end{array}$ & & Loamy Sand & $\begin{array}{l}\text { Present } \\
\text { Abundant }\end{array}$ & Normal \\
\hline
\end{tabular}


Table 3 (continued)

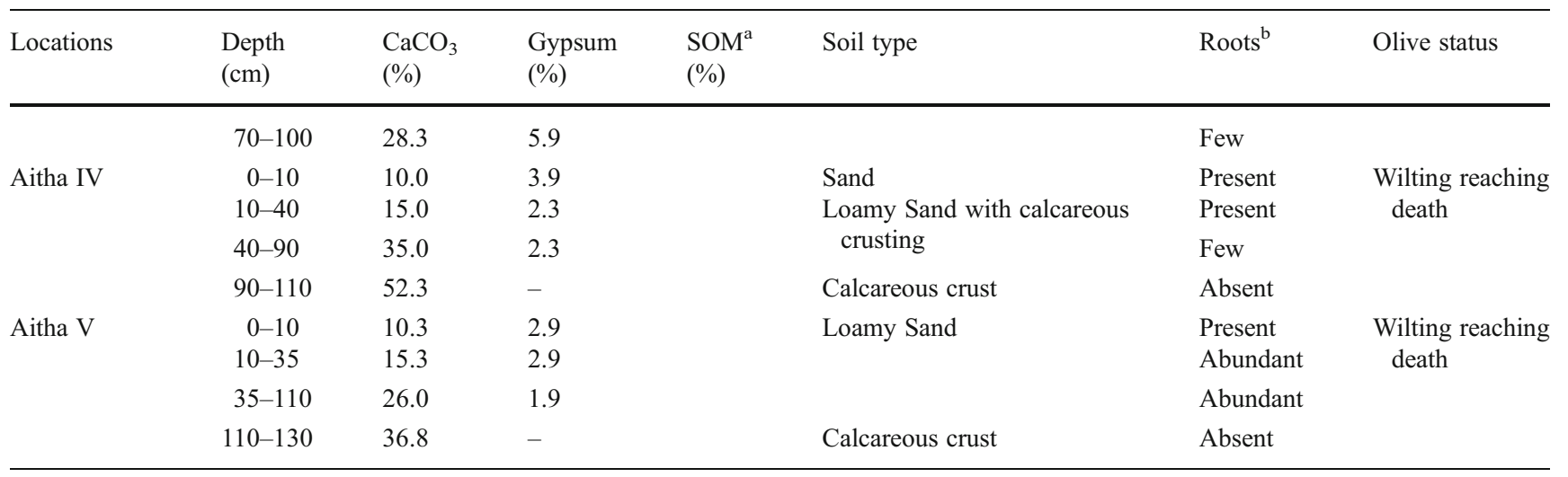

${ }^{\text {a }}$ Soil organic matter content

${ }^{\mathrm{b}}$ Abundant: more than, 0.1 roots $/ \mathrm{cm}^{2}$; present: between 0.01 and 0.1 roots $/ \mathrm{cm}^{2}$; few: less than 0.01 roots $/ \mathrm{cm}^{2}$; and absent: no roots

the negative effect of gypsum, and at the same time this latter increased soil compactness and water scarcity. In this type of soils, the deeper is the gypsum layer, the more important is the soil volume exploited by roots. In addition, dry soil compactness due to the presence of silt and clay in subsurface horizons limited deep root development. When a layer of fine elements is in top soil it prevents valorization of low rainfall by limiting water infiltration up to the root zone (Francis et al. 2007). In this case, the water is retained on the surface of the soil which receives enough solar energy to evaporate the water increasing water loss. Indeed, clay and silt-sized particles are important in the crusting process because they form bridges across pores and facilitate the clogging process (Francis et al. 2007). Conversely, a coarse layer enhances vertical water infiltration, subsurface water storage, and limits water evaporation. Breaking the impact of raindrops and minimizing colloid dispersion is widely recognized as the most important consequence of mulching the surface of crusting soils. Such layers significantly contribute to soil water balance through both enhanced infiltrability and reduced evaporation (Kemper 1993).

Local case studies permitted to detect factors other than water deficit, affecting olive tree resistance to drought which was not visible through national profiles. Fields containing old olive trees on a constraining soil are doubly exposed. In the broader context of global climate change, they will indubitably be firstly and severely affected. Thus growers must urgently adapt their production system to this novel situation, i.e., renewing old orchards, decreasing planting density in order to increase water reservoirs of limiting soils, changing species when soils contain gypsum, applying complementary irrigation when possible, etc.... This should be achieved with institutional support in implementing short- and long-term mitigation strategies.
Local authorities with extension services based on local vulnerability, tree age, and soil type maps, should provide the necessary knowledge to farmers to adapt to climate changes and thereby sustain olive production. They may use the GIS analysis to manage water allocation for irrigation of at risk orchards or to promote switching of the production, i.e., from olive orchards to pastoral land in area with gypsum and high water scarcity. At the national level, the identification and the mapping of the most vulnerable zones may be useful in targeting necessary actions. At the pre-alert level, the implementation of special water management strategies should be applied first in these zones and gradually extended to others with drought evolution.

\section{Conclusion}

Olive trees in Tunisia are susceptible to drought, a natural hazard that is becoming more frequent. This study showed that the vulnerability of rainfed olive tree to drought depends on factors other than genotype and rainfall deficit. Soil quality and tree age are among the most important factors influencing the resistance capacity of olive trees. However, many more factors must be included (e.g., cultivars, alternative crops, differences between cultural practices and application of new technologies, access to irrigation). The method used here permitted to develop a national vulnerability map of olive growing under drought stress at district and subdistrict levels identifying more at risk zones. By combining regional vulnerability mapping with local case studies, we have captured factors acting by accentuating or alleviating vulnerability, and thus extended the range of possible mitigation actions. 


\section{References}

Bakkenes M, Alkemade J, Ihle F, Leemans R, Latour J (2002) Assessing effects of forecasted climate change on the diversity and distribution of European higher plants for 2050. Global Change Biol 8:390-407

Boken VK (2009) Improving a drought early warning model for an arid region using a soil-moisture index. Appl Geogr 29:402-408

Brown RB (2003) Soil texture. Fact sheet SL-29 of the Soil and Water Science Department, Florida Cooperative Extension Service, Institute of Food and Agricultural Science, University of Florida, pp $1-8$

Brown RA, Rosenberg NJ (1997) Sensitivity of crop yield and water use to change in a range of climatic factors and $\mathrm{CO} 2$ concentrations: a simulation study applying EPIC to the central USA. Agric For Meteorol 83(3-4):171-203

Chartzoulakis K, Psarras G (2005) Global change effects on crop photosynthesis and production in Mediterranean: the case of Crete, Greece. Agric Ecosyst Environ 106:147-157

Chratzoulakis K, Patakas A, Bosabalibis AM (1999) Changes in water relations, photosynthesis and leaf anatomy induced by intermittent drought in two olive cultivars. Environ Exp Bot 42:113-120

Fabbri A, Bartolini G, Lombardi M, Kailis SM (2004) Olive propagation manual. CSIRO Publishing $145 \mathrm{p}$

FAO (2010) FAOSTAT the web database for time-series and crosssectional data relating to food and agriculture of Food and Agriculture Organization of the United Nations. http://faostat.fao.org/ site/567/DesktopDefault.aspx?PageID=567\#ancor

Fischlin A, Midgley GF, Price JT, Leemans R, Gopal B, Turley C, Rounsevell MDA, Dube OP, Tarazona J, Velichko AA (2007) Ecosystems, their properties, goods and services. In: Parry ML, Canziani OF, Palutikof JP, Van der Linden PJ, Hanson CE (eds) Climate change 2007: impacts, adaptation and vulnerability. Contribution of working group II to the fourth assessment report of the international panel on climate change, pp 211-272

Francis ML, Fey MV, Prinsloo HP, Ellis F, Mills AJ, Medinski TV (2007) Soils of Namaqualand: compensation for aridity. J Arid Environ 70:588-603

Fresco LO (1996) Agriculture in the lower Guadalhorce valley. Sustainable land use. Practical guide for the Alora Region, Spain. Agricultural University, Wageningen

Gargouri K, Rhouma A, Sahnoun A, Ghribi M, Bentaher H, Ben Rouina B, Ghrab M (2008) Assessment of the impact of climate change on olive growing in Tunisia using GIS tools. Options méditerranéennes Series A 80:349-352

Gibbs WJ, Maher JV (1967) Rainfall deciles as drought indicators (M. Commonwealth of Australia, Éd) Bureau of Meteorology Bulletin 48

Herrero J, Porta J (2000) The terminology and the concepts of gypsumrich soils. Geoderma 96:47-61
IPCC (2001) Climate change 2001: the scientific basis. Cambridge University Press, Cambridge

IPCC (2007) Climate change 2007: impacts, adaptation and vulnerability. In: Parry ML, Canziani OF, Palutikof JP, Van der Linden PJ, Hanson CE (eds) Contribution of working group II to the fourth assessment report of the intergovernmental panel on climate change. pp 273-313

Kemper W (1993) Effects of soil properties on precipitation use efficiency. Irrig Sci 14:65-73

Körner C, Sarris D, Christodoulakis D (2005) Long-term increase in climatic dryness in the East Mediterranean as evidenced for the island of Samos. Reg Environ Change 5:27-36

Lobell B, Field C, Nicholas Cahill K, Bonfils C (2006) Umpacts of future climate change on California perennial crop yields: model projections with climate and crop uncertainties. Agric For Meteorol 141:208-218

Loumou A, Giourga C (2003) Olive groves: the life and identity of the Mediterranean. Agr Hum Val 20:87-95

O’Brien K, Leichenko R, Kelkar U, Venema H, Aandahl G, Tmpkins H, Javed A, Bhadwal S, Barg S, Nygaard L, West J (2004) Mapping vulnerability to multiple stressors: climate change and globalization in India. Glob Environ Chang 14:303-313

Pauwels J, Van Rust E, Verloo M, Mvondo Z (1992) Pedology laboratory manual: soil and plant analysis methods. Centre Universitaire de Dschang. AGCD: Agricultural publication. 28

Petit RJ, Hampe A, Cheddadi R (2005) Climate changes and tree phylogeography in the Mediterranean. Taxon 54:877-885

Ragab R, Prudhomme C (2002) Climate change and water resources management in arid and semi-arid regions: prospective and challenges for the 21st century. Biosyst Eng 81:3-34

Sofo A, Manfreda S, Dichio B, Fiorentino M, Xiloyannis C (2007) The olive tree: a paradigm for drought tolerance in Mediterranean climates. Hydrol Earth Syst Sci Discuss 4:2811-2835

Spennemann DH, Allen R (2000) From cultivar to weed: the spread of olives in Australia. Olivae 82:44-46

Thuiller W, Lavorel S, Araujo B, Sykes M, Prentice I (2005) Climate change threats to plant diversity in Europe. Proc Natl Acad Sci USA 102:8245-8250

Tsakiris G (2009) A pradigm for applying risk and hazard concepts in proactive planning. In: Iglesias A, Garrote L, Cancellier A, Cubillo F, and Wilhite DA (Éds) Advances in natural and technological hazards research. Copping with drought risk in agriculture and water supply systems 26:81-91

Tsakiris G, Pangalou D (2009) Drought chracterisation in the Mediterranean. In: Iglesias A, Garrote L, Cancellier A, Cubillo F, and Wilhite DA (Éds) Advances in natural hazards research. Coping with drought risk in agriculture and water supply systems $26: 69-$ 80

Ubimtseva E, Henebry GM (2009) Climate and environmental change in arid central Asia: impacts, vulnerability, and adaptations. J Arid Environ 73:963-977 